\title{
Analisis Kesesuaian Kandungan Energi dan Zat Gizi Makro Rencana Menu dengan Standar Diet untuk Pasien Diabetes Mellitus
}

\section{Conformity Analysis of Energy and Macronutrient between Planned Menu and Diet Manuals for Diabetes Mellitus Inpatient}

\author{
Afifah Yasyfa Dhiyanti*, Laksmi Karunia Tanuwijaya ,Eva Putri Arfiani
}

\begin{abstract}
ABSTRAK
Latar Belakang: Pengaturan diet pada pasien rawat inap dengan Diabetes Mellitus bertujuan untuk mencapai dan mempertahankan kadar glukosa darah normal. Ketatnya pemantauan asupan makan pasien ditujukan untuk mencegah komplikasi akibat kondisi hipoglikemia dan hiperglikemia.

Tujuan: Mengetahui kesesuaian kandungan energi dan zat gizi makro rencana menu ABC dengan standar diet 1700 kkal.

Metode: Penelitian ini merupakan penelitian cross sectional dengan pendekatan deskriptif. Variabel penelitian adalah kandungan energi dan zat gizi makro standar diet dan rencana menu untuk pasien Diabetes Mellitus. Ada tidaknya kesesuaian diketahui dengan cara mengidentifikasi kandungan energi dan zat gizi makro pada siklus menu $A B C$ dan standar resep menggunakan Nutrisurvey, DKBM, dan pedoman perkiraan penyerapan minyak, kemudian dibandingkan dengan kandungan energi dan zat gizi makro pada standar diet $1700 \mathrm{kkal}$.

Hasil: Standar diet 1700 kkal meliputi 1700 kkal energi, 63,8 gram protein, 47,2 gram lemak, dan 255 gram karbohidrat. Rerata energi menu A 1743,5 $\pm 147 \mathrm{kkal}$, menu B 1710,4 4 137,8 kkal, dan menu C 1744,6 \pm 143,5 kkal. Rerata protein menu A 68,2 \pm 4 gram, menu B 69,3 $\pm 4,2$ gram, dan menu C $70 \pm 4,6$ gram. Rerata lemak menu A 71,2 $\pm 10,5$ gram, menu B 68,4 $\pm 10,3$ gram, dan menu C 67,7 $\pm 11,1$ gram. Rerata karbohidrat menu A 212,3 \pm 14 gram, menu B 210,5 \pm 14 gram, dan menu C 214,6 $\pm 13,8$ gram.
\end{abstract}

Kesimpulan: Terdapat ketidaksesuaian kandungan energi 0,6-22\%, protein 0,2-27\%, lemak 20-104\%, dan karbohidrat 7-25\% pada rencana menu $A B C$ dengan standar diet 1700 kkal.

Kata Kunci: ketidaksesuaian, rencana menu, standar diet.

\section{ABSTRACT}

Background: Diabetes Mellitus diet regulation aims to achieve and maintain controlled blood glucose levels. The strict monitoring of patient's intake is intended to prevent complications due to hypoglycemia and hyperglycemia.

Objectives: To determine the conformity of energy and macronutrients between ABC menu planned and $1700 \mathrm{kcal}$ diet standard.

Methods: This study was a cross sectional study with descriptive approach. Research variables were energy and macronutrients of diet manuals and menu planned for Diabetes Mellitus inpatients. The conformity was known by identifying energy and macronutrients in the $A B C$ menu cycle and standard recipes using Nutrisurvey Software and guidelines for estimates oil absorption, then compared with the energy and macronutrients on the $1700 \mathrm{kcal}$ diet standard.

Results: Standard $1700 \mathrm{kcal}$ diet consisted of $1700 \mathrm{kcal}$ energy, 63.8 grams protein, 47.2 grams fat, and 255 grams carbohydrate. The average menu A provided $1743.5 \pm 147 \mathrm{kcal}$ of energy, menu B $1710.4 \pm 137.8 \mathrm{kcal}$, and menu $C$ $1744.6 \pm 143.5 \mathrm{kcal}$. The average menu A provided $68.2 \pm 4$ grams of protein, menu $B \quad 69.3 \pm 4.2$ grams, and menu $C 70 \pm 4.6$ grams. The average menu A contained $71.2 \pm 10.5$ grams of fat, menu $B 68.4 \pm 10.3 \mathrm{grams}$, and menu $C 67.7 \pm 11.1 \mathrm{grams}$. The average menu A consisted $212.3 \pm 14$ grams carbohydrate, menu B 210.5 \pm 14 grams, and menu C $214.6 \pm 13.8$ grams.

Conclusions: Compared to $1700 \mathrm{kcal}$ standard diet, the discrepancies of energy are at $0.6-22 \%$, protein $0.2-27 \%$, fat 20 $104 \%$, and carbohydrates $7-25 \%$.

Keywords: diet manuals, discrepancy, menu planned 


\author{
*Koresponden: \\ Afifah Yasyfa Dhiyanti \\ Email: dhiyantiafifah@gmail.com \\ Prodi S-1 IImu Gizi Fakultas Kedokteran Universitas Brawijaya, Jalan Veteran Malang 65145
}

\section{PENDAHULUAN}

Diabetes Mellitus saat ini menjadi salah satu penyebab kematian terbesar di Indonesia. Data Riskesdas menunjukkan adanya tren peningkatan prevalensi Diabetes di Indonesia dari tahun 2007 hingga tahun 2013, yaitu dari $5,7 \%$ menjadi $6,9 \%$ atau setara dengan 9,1 juta penderita ${ }^{1}$. Pada tahun 2008 diketahui jumlah pasien rawat inap di Indonesia dengan diagnosa Diabetes Mellitus adalah sebanyak 56.378 pasien ${ }^{2}$. Jumlah pasien Diabetes Mellitus yang tercatat pada bagian penyakit dalam RS Saiful Anwar Malang 2008-2010 sebanyak berturut-turut 1346 pasien, 1577 pasien, dan 1685 pasien. Berdasarkan survei pada tahun 2013, didapatkan data bahwa Diabetes Mellitus merupakan salah satu dari 10 jenis penyakit dengan jumlah pasien rawat inap terbanyak di RSUD Tugurejo Semarang. Terhitung dari bulan Januari hingga Maret tahun 2014, pasien rawat inap dengan diagnosa utama Diabetes Mellitus berjumlah 87 orang $^{3}$.

Tujuan pengaturan diet pada pasien rawat inap dengan Diabetes Mellitus adalah untuk mencapai dan mempertahankan kadar glukosa darah normal atau mendekati normal serta mencegah dan menghambat komplikasi kronis Diabetes Mellitus ${ }^{4}$. Untuk mencapai kadar glukosa darah yang terkontrol perlu adanya ketepatan pemberian diet serta pemantauan makanan yang dikonsumsi. Ketatnya pemantauan asupan makan pasien ditujukan untuk mencegah komplikasi akibat kondisi hipoglikemia dan hiperglikemia. Hal inilah yang menyebabkan pada penderita Diabetes Mellitus terjadi speningkatan resiko serangan jantung serta komplikasi lain $^{5}$.

Pada pasien rawat inap, instalasi gizi memiliki kewajiban untuk menyediakan makanan yang dapat memenuhi kebutuhan gizi serta mampu mendukung proses penyembuhan penyakit pasien selama menjalani rawat inap di rumah sakit ${ }^{6}$. Alur proses pelayanan gizi pasien rawat inap berawal dari penilaian status gizi, penyusunan preskripsi diet hingga penerjemahan preskripsi diet menjadi menu makanan sesuai standar rumah sakit. Dalam proses tersebut, perlu adanya standar pemberian makanan atau standar diet. Dokter menentukan dan memesan diet yang dibutuhkan, kemudian instalasi gizi merencanakan menu berdasarkan pada standar diet ${ }^{7}$. Rencana menu rumah sakit umumnya berupa sebuah siklus menu yang terdiri dari serangkaian menu untuk jangka waktu tertentu. Rencana menu untuk pasien Diabetes Mellitus di lokasi penelitian ini dibedakan menjadi tiga jenis, yaitu menu A (Alergi), menu B (Biasa), dan menu C (Cincang). Jenis rencana menu dibedakan berdasarkan peruntukan pasien, jenis lauk hewani yang digunakan, dan bentuk makanan saat disajikan.

Penelitian yang dilakukan Kim et al., tahun 2010 di tiga rumah sakit di Korea menunjukkan rencana menu untuk penderita Diabetes Mellitus di salah satu rumah sakit didapatkan data kesesuaian kandungan zat gizi protein $<90 \%{ }^{7}$. Meskipun memiliki perbedaaan yang kecil, ketidaksesuaian kandungan zat gizi pada rencana menu dengan standar diet rumah sakit tidak boleh diabaikan. Rencana menu adalah salah satu kontrol yang paling penting dalam pelayanan gizi di rumah sakit karena penyediaan makanan untuk pasien berpedoman pada rencana menu yang telah dibuat. Rencana menu berperan sebagai standar dalam mengevaluasi makanan yang disajikan kepada pasien rawat inap. Menu yang tepat harus ditekankan dan proses evaluasi menu haruslah dijalankan.

Penelitian ini bertujuan untuk mengetahui kesesuaian kandungan energi dan zat gizi makro rencana menu dengan standar diet pada pasien rawat inap Diabetes Mellitus. Kandungan energi dan zat gizi makro rencana menu yang tidak sesuai merupakan salah satu penyebab tidak terpenuhinya kecukupan kebutuhan gizi pasien, baik melebihi kebutuhan ataupun kurang dari kebutuhan pasien. Penelitian ini diharapkan mampu memberikan manfaat sebagai evaluasi penyelenggaraan makanan untuk pasien Diabetes Mellitus di rumah sakit.

\section{METODE}

Penelitian ini merupakan penelitian cross sectional dengan pendekatan deskriptif. Penelitian dilakukan pada November 2018 di rumah sakit umum milik sebuah universitas swasta di Kota Malang, selanjutnya lokasi penelitian diistilahkan dengan sebutan RS X. Variabel penelitian terdiri dari kandungan energi dan zat gizi makro standar diet dan kandungan energi dan zat gizi makro rencana menu. Subjek pada penelitian ini adalah Ahli Gizi RS X. Objek yang digunakan dalam penelitian ini adalah form standar diet, siklus menu dan standar resep pasien rawat inap Diabetes Mellitus di RS X. Penelitian dilakukan dengan melakukan observasi standar diet, siklus menu, dan standar resep serta wawancara dengan Ahli Gizi.

Data yang dikumpulkan pada penelitian ini terdiri dari data primer dan sekunder. Data primer meliputi kandungan energi dan zat gizi makro pada standar diet 1700 kkal dan rencana menu A, B, dan C serta alasan 
pemilihan bahan makanan dan metode pengolahan pada rencana menu pasien Diabetes Mellitus, sedangkan data sekunder adalah standar diet 1700 kkal, siklus menu, dan standar resep. Kandungan energi dan zat gizi makro pada rencana menu diketahui melalui software Nutrisurvey, DKBM, TKPI, dan pedoman perkiraan penyerapan minyak goreng.

Penelitian dilakukan setelah mendapatkan izin dari Komisi Etik Fakultas Kedokteran Universitas Brawijaya dan Diklit Rumah Sakit X. Pengambilan data diawali dengan observasi standar diet RS, siklus menu, dan standar resep untuk pasien rawat inap Diabetes Mellitus. Selanjutnya, dilakukan pencatatan kandungan energi dan zat gizi makro pada standar diet RS. Selain itu dilakukan pula pencatatan jenis dan jumlah bahan makanan yang digunakan pada siklus menu dan standar resep. Kemudian dilakukan pengambilan data terkait alasan pemilihan bahan makanan dan metode pengolahan kepada Kepala Instalasi Gizi. Kandungan energi dan zat gizi makro yang terkandung pada siklus menu dan standar diet diidentifikasi menggunakan software Nutrisurvey, DKBM, TKPI, dan pedoman perkiraan penyerapan minyak goreng. Data kandungan energi dan zat gizi makro pada rencana menu dan standat diet RS kemudian dianalisis menggunakan Microsoft Excel untuk mengetahui kesesuaikan antara keduanya.

\section{HASIL DAN PEMBAHASAN}

Instalasi Gizi RS X menerapkan dua jenis standar diet untuk pasien rawat inap Diabestes Mellitus, yaitu standar diet 1500 dan standar diet 1700. Tabel 1 menunjukkan standar diet 1500 dan 1700 memiliki perbedaan kandungan energi dan zat gizi makro yang tidak begitu besar. Protein dan karbohidrat pada standar diet 1700 lebih tinggi 13,3\% dari standar diet 1500, sedangkan lemak lebih tinggi $13,2 \%$. Dua jenis Standar diet Diabetes Mellitus yang tersedia kemudian oleh Instalasi Gizi RS X diterjemahkan menjadi rencana menu. Standar diet 1700 diterjemahkan menjadi tiga jenis rencana menu, yaitu menu $A$, menu $B$, dan menu $C$.

Gambar 1 menunjukkan bahwa perbedaan kandungan energi terbesar pada perbandingan rencana menu dengan standar diet terdapat pada siklus menu ke7 (tujuh) untuk menu cincang, dan siklus menu ke-9 (sembilan) untuk menu alergi dan biasa. Secara keseluruhan kandungan energi tertinggi dimilki oleh menu $C$, sedangkan kandungan energi terendah dimiliki oleh menu B. Gambar 2 menunjukkan bahwa perbedaan kandungan protein tertinggi untuk ketiga jenis menu terdapat pada siklus menu ke-9 (sembilan). Secara keseluruhan kandungan protein tertinggi dimilki oleh menu $C$, sedangkan kandungan protein terendah dimiliki oleh menu A. Gambar 3 menunjukkan bahwa perbedaan kandungan lemak tertinggi terdapat pada siklus menu ke7 (tujuh) untuk menu cincang, dan siklus menu ke-9 (sembilan) untuk menu alergi dan biasa. Secara keseluruhan kandungan lemak tertinggi dimilki oleh menu A, sedangkan kandungan lemak terendah dimiliki oleh menu C. Gambar 4 menunjukkan bahwa sebelas dari sebelas siklus menu pada siklus menu alergi, biasa, dan cincang memiliki kandungan karbohidrat lebih rendah dari standar diet 1700. Secara keseluruhan kandungan karbohidrat tertinggi dimilki oleh menu C, sedangkan kandungan karbohidrat terendah dimiliki oleh menu B.

Tabel 1. Kandungan Energi dan Zat Gizi Makro pada Standar Diet Diabetes Mellitus

\begin{tabular}{ccccc}
\hline \multirow{2}{*}{ Jenis Standar Diet } & Energi (kkal) & Protein (gram) & Lemak (gram) & Karbohidrat (gram) \\
\hline DM 1700 & 1700 & 63,8 & 47,2 & 255 \\
DM 1500 & 1500 & 56,3 & 41,7 & 225 \\
\hline
\end{tabular}

Tabel 2. Perbedaan Rencana Menu A, B, dan C

\begin{tabular}{llll}
\hline \multicolumn{1}{c}{ Kriteria } & \multicolumn{1}{c}{ Menu A } & \multicolumn{1}{c}{ Menu B } & Menu C \\
\hline Peruntuk-kan & $\begin{array}{l}\text { Pasien DM yang memiliki } \\
\text { alergi }\end{array}$ & $\begin{array}{l}\text { Pasien DM murni atau dengan } \\
\text { komplikasi namun tidak membutuh- } \\
\text { kan makanan dengan bentuk } \\
\text { makanan cincang. }\end{array}$ & $\begin{array}{l}\text { Pasien DM yang } \\
\text { membutuh- } \\
\text { kan makanan dengan } \\
\text { bentuk makanan cincang }\end{array}$ \\
$\begin{array}{l}\text { Jenis lauk hewani } \\
\text { yang digunakan } \\
\text { Bentuk makanan }\end{array}$ & Daging sapi dan bakso & Ikan, ayam, daging sapi, dan telur. & $\begin{array}{l}\text { lkan, ayam, daging sapi, } \\
\text { dan telur } \\
\text { Makanan biasa }\end{array}$ \\
\hline
\end{tabular}


Pada penelitian ini didapatkan bahwa standar diet pasien Diabetes Mellitus di RS X tidak sama dengan standar diet yang ditentukan oleh Almatsier pada tahun $2010^{8}$. Instalasi Gizi RS X menentukan jumlah energi dan zat gizi makro pada standar diet DM berlandaskan pada proporsi protein $15 \%$, lemak $25 \%$, dan karbohidrat $60 \%$. Hal ini sejalan dengan ketentuan yang telah dikeluarkan oleh PERKENI (2015) mengenai Terapi Nutrisi Medis (TNM) untuk pasien Diabetes Mellitus, yaitu komposisi makanan yang dianjurkan meliputi $45-65 \%$ karbohidrat, $20-25 \%$ lemak, dan $10-20 \%$ protein ${ }^{9}$.

Alur perencanaan menu pasien diawali dengan menerjemahkan standar diet menjadi beberapa menu yang membentuk sebuah siklus. Kombinasi jenis lauk hewani dalam siklus menu secara signifikan dapat mempengaruhi kandungan energi, protein, dan lemak. Perbedaan rencana menu A, B, dan C terletak pada penggunaan jenis lauk hewani. Menu $A$ menggunakan lauk hewani jenis daging sapi (31 menu) dan bakso (2 menu), menu B menggunakan lauk hewani jenis ayam (10 menu), daging sapi (11 menu), telur ayam (2 menu), dan ikan (10 menu), sedangkan menu $\mathrm{C}$ menggunakan ayam (11 menu), daging sapi (8 menu), telur ayam (4 menu), bakso (1 menu), dan ikan (9 menu).

Gambar 1 menggambarkan bahwa dari 3 jenis rencana menu yang dimiliki RS $X$, kandungan energi tertinggi dimiliki oleh Menu $C$ kemudian berturut-turut Menu A dan Menu B. Berdasarkan gambar 2 dapat diketahui bahwa jika dibandingkan dengan Menu A dan B, Menu $C$ memiliki kandungan protein yang lebih tinggi. Pola ini terbentuk akibat adanya kombinasi penggunaan jenis lauk hewani pada tiap siklusnya. Menu C memiliki kandungan energi dan protein tertinggi disebabkan karena pada menu $C$ penggunaan ayam lebih sering dibandingkan menu A dan B. Berdasarkan standar porsi RS $X$, ayam merupakan jenis lauk hewani dengan kandungan protein paling tinggi dibandingkan jenis lauk hewani lain yang digunakan.

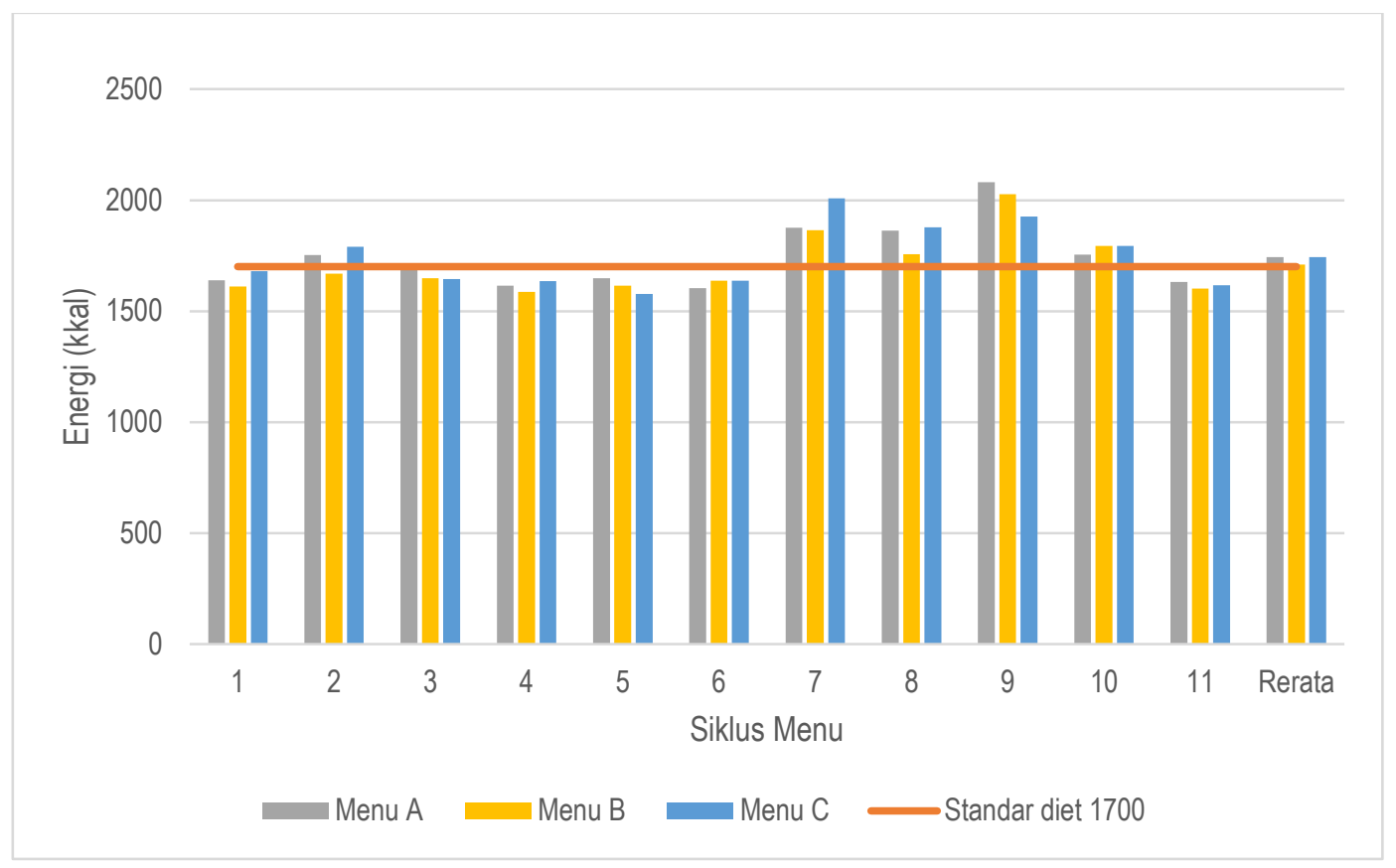

Gambar 1. Perbandingan Kandungan Energi Menu A, B, dan C

Kandungan energi pada rencana menu tidak sesuai dengan standar diet yang diterapkan di RS (menu A $1743,5 \pm 147 \mathrm{kkal}$, menu B 1710,4 $\pm 137,8 \mathrm{kkal}$, dan menu C 1744,6 $\pm 143,5$ kkal). Ketidaksesuaian ini terjadi karena dalam proses penyusunan menu dan standar resep, Instalasi Gizi kurang memperhatikan kandungan energi pada bahan makanan yang digunakan selama proses pengolahan selain bahan makanan utama. Bahan makanan yang digunakan sebagai bumbu ataupun bahan pendukung seperti tepung, telur, dan keju memiliki peran dalam menambah energi pada makanan. Hal ini didukung dengan hasil observasi pada lembar perencanaan menu Instalasi Gizi RS X untuk pasien DM, dimana pada lembar tersebut hanya menyantumkan bahan makanan utama tanpa menyertakan bahan makanan pendukung dalam perhitungan energi saat membuat rencana menu. Pada proses penyusunan rencana menu, Instalasi Gizi RS $\mathrm{X}$ menentukan kandungan energi bahan makanan menggunakan DBMP (Daftar Bahan Makanan Penukar). Informasi nilai energi dan zat gizi makro bahan makanan pada DBMP terbatas, tidak semua bahan makanan yang digunakan dalam siklus menu RS $X$ tersedia dalam DBMP.

Berdasarkan gambar 2 dapat diketahui bahwa kandungan protein pada rencana menu untuk pasien rawat inap Diabetes Mellitus tidak sesuai dengan standar diet RS (menu A 68,2 \pm 4 gram, menu B 69,3 $\pm 4,2$ gram, dan menu $C 70 \pm 4,6$ gram). Perbedaan kandungan protein tertinggi terdapat pada siklus menu ke sembilan. 
Penggunaan keju sebagai bumbu pada siklus menu sembilan tepatnya pada menu "sayur rebus saus keju" diperkirakan sebagai penyebab besarnya perbedaan kandungan protein. Keju yang ditambahkan pada menu ini berupa keju cheddar sejumlah 5 gram untuk satu porsi. Keju merupakan produk olahan susu yang diketahui sebagai salah satu pangan sumber protein dan kalsium ${ }^{10}$. Penggunaan keju sebagai bumbu pada siklus menu sembilan tidak masuk dalam perhitungan energi dan protein saat perencanaan menu, sehingga terjadi kelebihan protein pada siklus sembilan.

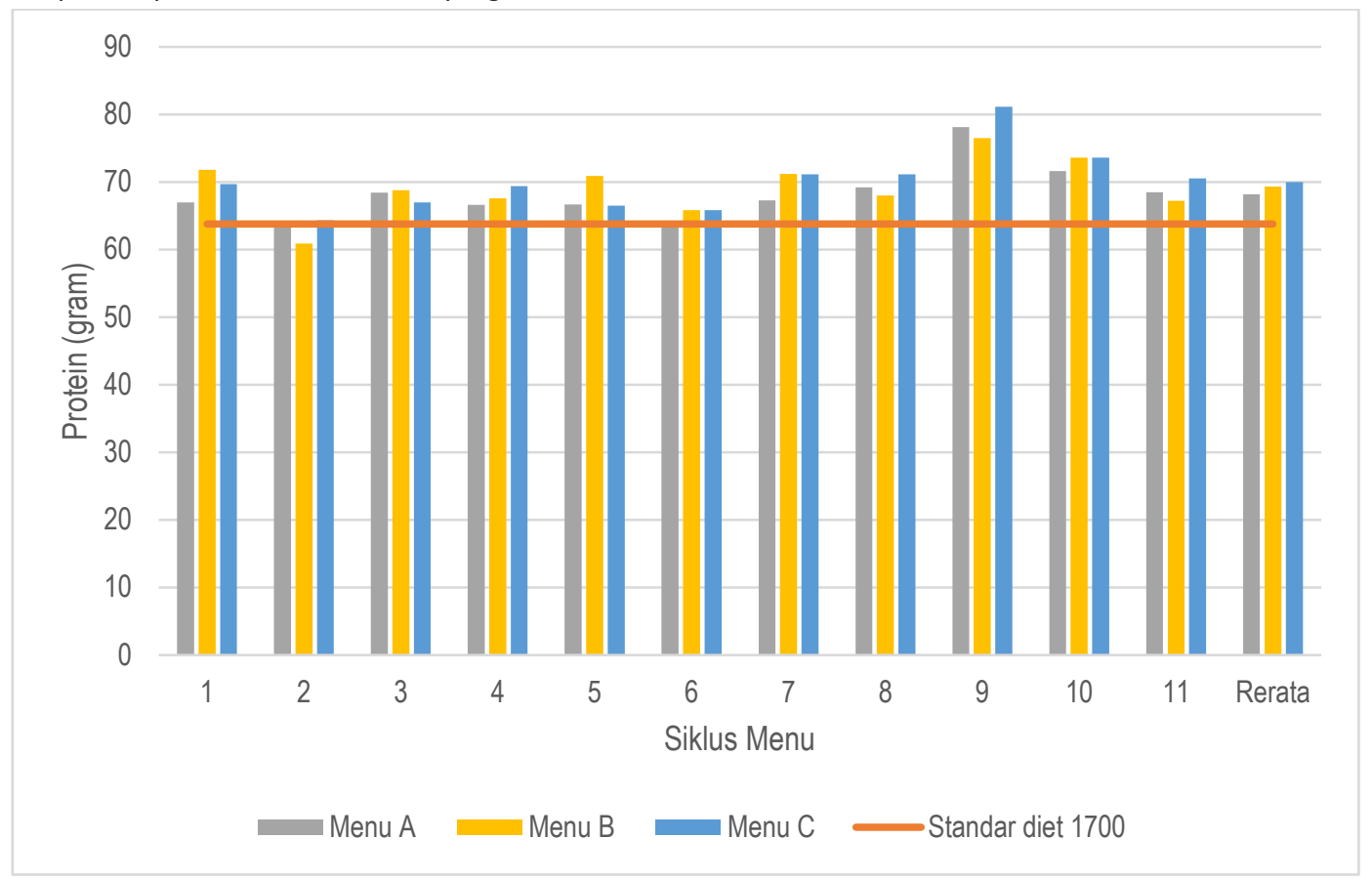

Gambar 2. Perbandingan Kandungan Protein Menu A, B, dan C

Pengaturan diet untuk pasien Diabetes Mellitus salah satunya adalah mengonsumsi makanan dengan jumlah energi yang tepat. Penelitian Fitri \& Wirawanni (2014) menunjukkan bahwa hubungan konsumsi total energi dengan kadar glukosa darah bersifat positif, semakin tinggi asupan energi maka kadar glukosa darah juga akan meningkat ${ }^{11}$. Kadar glukosa darah penderita Diabetes Mellitus dapat pula dihubungkan dengan jumlah protein yang dikonsumsi. Edy (2017) melalui penelitiannya di RSUD Panembahan Senopati Bantul Yogyakarta menyatakan asupan protein melebihi kebutuhan menyebabkan kenaikan kadar glukosa darah. Hal ini terjadi karena dalam tubuh asupan protein akan diubah menjadi asam amino yang kemudian digunakan untuk membentuk glukosa ${ }^{12}$.

Serupa dengan energi dan protein, kelebihan asupan lemak pada penderita Diabetes Mellitus tidak dapat diabaikan begitu saja. Rekomendasi pembatasan konsumsi lemak untuk penderita Diabetes Mellitus didasarkan pada tingginya resiko penyakit kardiovaskuler serta fakta bahwa lemak jenuh mempengaruhi peningkatan kolesterol LDL pada metabolisme lemak, resistensi insulin, dan tekanan darah ${ }^{4}$. Gambar 3 menunjukkan bahwa kandungan lemak tertinggi dimiliki oleh Menu A sedangkan kandungan lemak terendah dimiliki oleh menu C. Sumbangan lemak tertinggi terdapat pada menu $A$, hal ini disebabkan karena pada menu A selama 11 siklus menu menggunakan daging sapi dan bakso sapi. Berdasarkan standar porsi RS X, daging sapi dan bakso sapi tergolong kedalam jenis lauk hewani dengan kandungan lemak tinggi dan sedang dibandingkan jenis lauk hewani lain.

Jika dibandingkan dengan standar diet RS, Gambar 3 menunjukkan bahwa kandungan lemak pada menu alergi, biasa, dan cincang lebih tinggi dibandingkan kandungan lemak pada standar diet 1700 (menu A 71,2 \pm 10,5 gram, menu B 68,4 $\pm 10,3$ gram, dan menu C $67,7 \pm$ 11,1 gram). Kelebihan kandungan lemak ini disebabkan karena selama perencanaan menu Instalasi Gizi kurang memperhatikan penyerapan minyak selama proses pengolahan. Hal ini didukung dengan pernyataan Kepala Instalasi Gizi RS X:

"....kalau untuk metode kayak goreng-goreng gitu kita sebenernya sih lebih nggak terlalu memperhatikan biasanya."

Selama proses perencanaan menu Ahli Gizi tidak secara khusus mempertimbangkan frekuensi metode pengolahan dengan cara menggoreng. Rata-rata dalam satu hari terdapat 3-4 menu yang dimasak melalui proses penggorengan. Pasien Diabetes Mellitus dianjurkan hanya mendapatkan satu jenis makanan yang digoreng dalam satu kali waktu makan, selebihnya makanan dapat diolah dengan dikukus, panggang, maupun rebus ${ }^{13}$. Metode menggoreng erat kaitannya dengan penyerapan minyak 
pada makanan. Jumlah serapan minyak pada bahan makanan akan berbeda antar jenis bahan makanan dan antar metode pengolahan, sehingga perlu untuk memperhitungkan penyerapan minyak pada masingmasing bahan makanan yang digunakan ${ }^{14}$. Jika dalam satu siklus menggunakan beberapa bahan dengan persentase penyerapan minyak yang tinggi secara bersamaan maka akan berdampak pada tingginya lemak yang terkandung dalam siklus menu tersebut. Penggunaan keju sebagai bumbu seperti pada siklus menu sembilan dapat pula menyebabkan terjadi peningkatan kandungan lemak pada makanan.

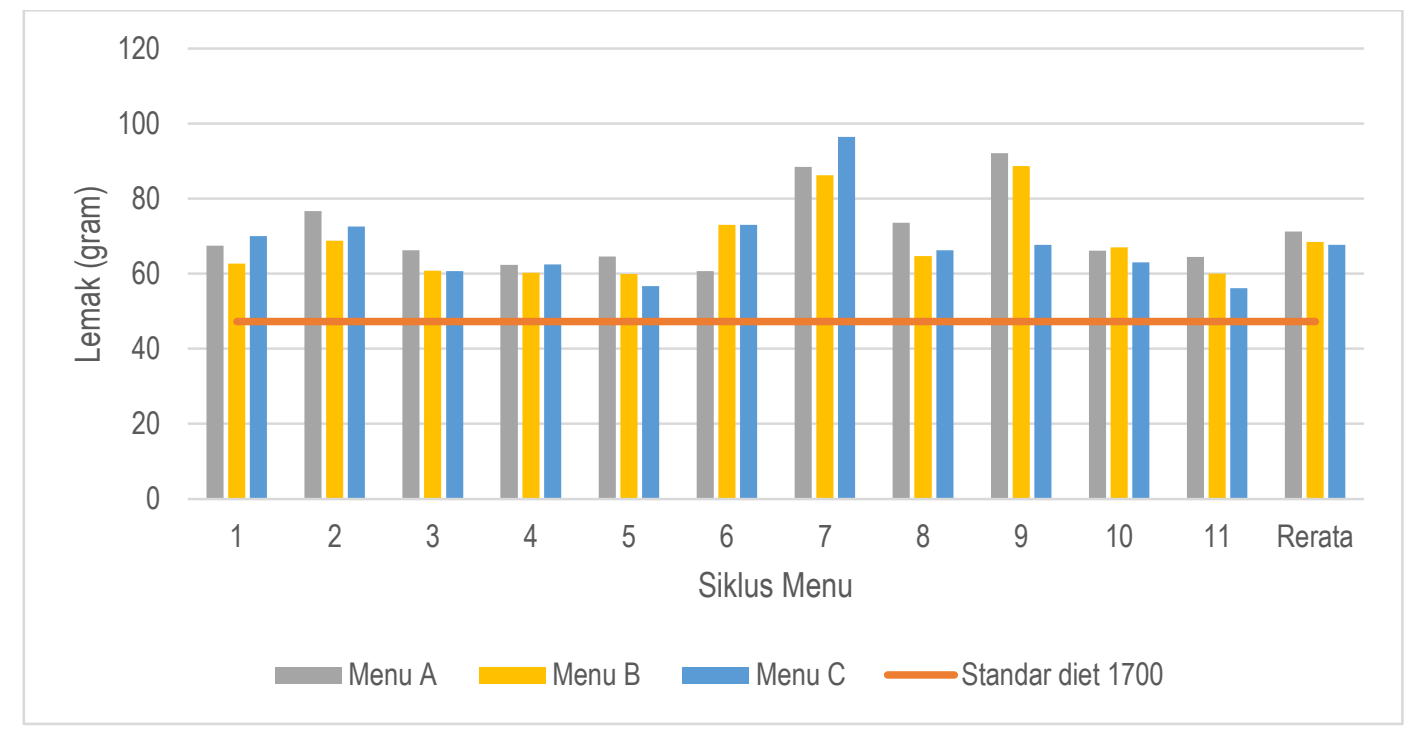

Gambar 3. Perbandingan Kandungan Lemak Menu A, B, dan C

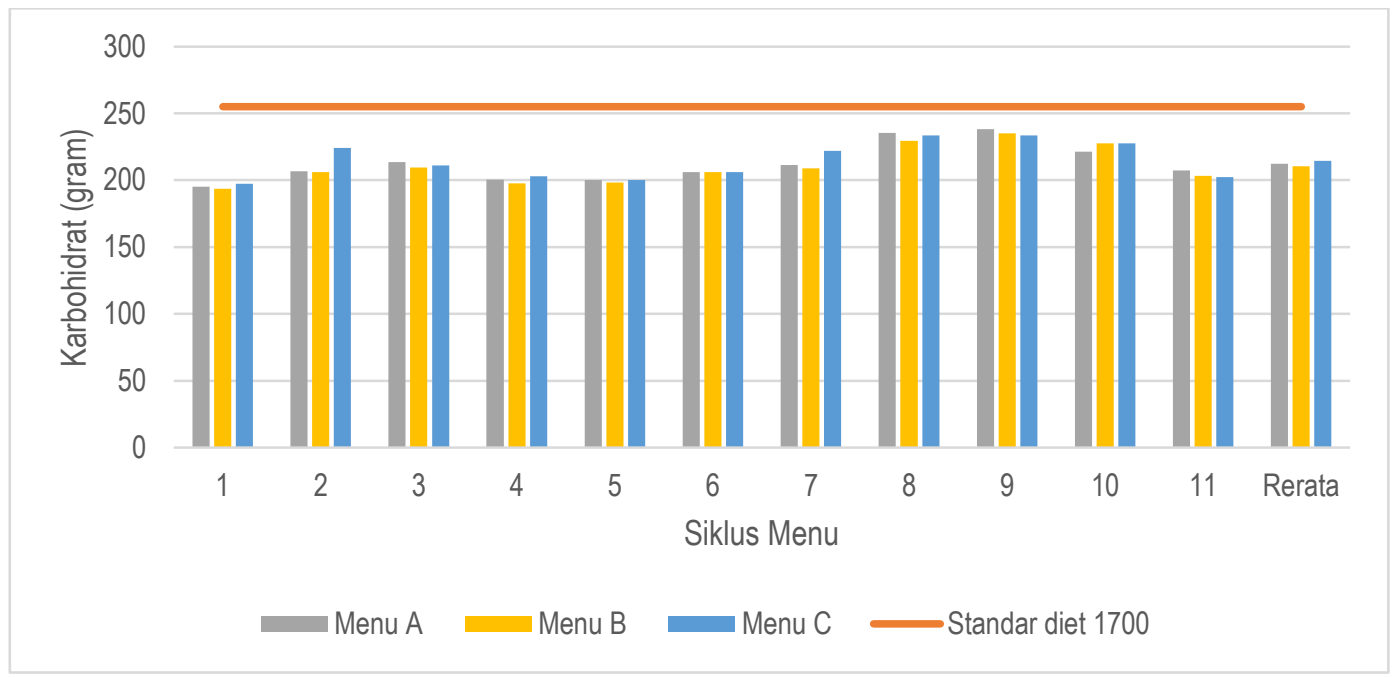

Gambar 4. Perbandingan Kandungan Karbohidrat Menu A, B, dan C

Tatalaksana terapi gizi untuk penderita Diabetes Mellitus sangat erat kaitannya dengan pengaturan asupan karbohidrat. Pengaturan jumlah asupan karbohidrat menjadi poin utama yang harus diterapkan untuk mencapai kestabilan kadar glukosa darah pasien Diabetes Mellitus ${ }^{15}$. Namun asupan karbohidrat sangat rendah pada pasien Diabetes Mellitus tidak dianjurkan. Beberapa jaringan dan sel tubuh hanya mampu berfungsi dengan baik apabila tersedia glukosa darah dalam jumlah yang cukup. Eritrosit dan susunan saraf pusat membutuhkan glukosa sebagai sumber energi ${ }^{11}$. Berdasarkan gambar 4 diketahui bahwa kandungan karbohidrat pada rencana menu untuk pasien rawat inap Diabetes Mellitus tidak sesuai dengan standar diet RS (menu A 212,3 \pm 14 gram, menu B 210,5 \pm 14 gram, dan menu C $214,6 \pm 13$,8 gram). Sebelas siklus Menu A, B, dan $\mathrm{C}$ memiliki kandungan karbohidrat dibawah kandungan karbohidrat standar diet 1700 . Hal ini merupakan akibat dari kurangnya besar porsi makanan sumber karbohidrat selain makanan pokok yang diberikan kepada pasien, seperti sayur dan buah. Kandungan karbohidrat pada jenis diet alergi, biasa, maupun cincang memang dibawah kandungan karbohidrat pada standar diet, namun jumlah karbohidrat pada setiap menu tidak kurang dari 130 
gram. Hal ini sesuai dengan rekomendasi PERKENI (2015) bahwa pembatasan karbohidrat $<130$ gram/hari pada pasien Diabetes Mellitus tidak disarankan ${ }^{9}$.

Rata-rata rencana menu baik pada menu A, B, maupun $C$ memiliki kandungan energi lebih tinggi, protein lebih tinggi, lemak lebih tinggi, dan karbohidrat lebih rendah dari standar diet. Ketidaksesuaian kandungan energi dan zat gizi makro disebabkan karena selama proses penyusunan rencana menu Instalasi Gizi hanya memperhatikan kecukupan energi saja tanpa memperhatikan kecukupan zat gizi makro. Ahli Gizi juga tidak memasukkan bahan makanan pendukung selama perhitungan kandungan gizi rencana menu. Selain itu, Ahli Gizi menggunakan DBMP dalam menentukan kandungan energi dan zat gizi makro bahan makanan. Adanya ketidaksesuaian energi dan zat gizi makro antara standar diet dengan rencana menu didapatkan pula pada penelitian Kim et al., (2010) di 2 rumah sakit di Seoul dan 1 rumah sakit di Chon-An Korea. Pada Rumah Sakit A didapatkan bahwa rencana menu untuk pasien Diabetes Mellitus memenuhi $98-105 \%$ energi dan zat gizi makro pada standar diet. Pada Rumah Sakit B dan C, kandungan energi dan zat gizi makro pada rencana diet tidak memenuhi standar gizi pada standar diet namun perbedaan tersebut kurang dari $10 \%{ }^{7}$.

\section{KESIMPULAN}

Pada penelitian ini dapat ditarik kesimpulan bahwa terdapat ketidaksesuaian kandungan energi dan zat gizi makro rencana menu $A, B$, maupun $C$ dengan standar diet rumah sakit pada pasien rawat inap Diabetes Mellitus Di RS $X$. Ketidaksesuaian kandungan energi dan zat gizi makro pada rencana menu dengan standar diet disebabkan karena Instalasi Gizi selama penyusunan menu dan standar resep menggunakan Daftar Penukar Bahan Makanan, hanya memperhitungkan kandungan energi rencana menu saja serta kurang memperhatikan kandungan bahan makanan pendukung.

\section{ACKNOWLEDGEMENT}

Penulis menyampaikan ucapan terima kasih kepada Pimpinan Rumah Sakit, Kepala Instalasi Gizi, Ahli Gizi serta Karyawan yang bertugas di dapur instalasi gizi yang telah memberikan izin penelitian, serta semua rekan yang telah membantu terselesaikannya pelaksanaan penelitian ini.

\section{REFERENS}

1. Kemenkes RI. Menkes: Mari Kita Cegah Diabetes dengan Cerdik. (2016). Available at: http://www.depkes.go.id/article/print/16040700 002/menkes-mari-kita-cegah-diabetes-dengancerdik.html.

2. Depkes RI. Profil Kesehatan Indonesia 2008. (Departemen Kesehatan Republik Indonesia, 2009).

3. Aristika, D. Deskripsi Karakteristik Penderita, Lama Dirawat (LOS) dan Epidemiologi Penyakit Dsiabetes Mellitus Pada Pasien JKN di RSUD Tugurejo Semarang Triwulan I Tahun 2014. (2014).

4. Azrimaidaliza. Asupan Zat Gizi dan Penyakit Diabetes Mellitus. J. Kesehat. Masy. 6, 36-41 (2011).

5. Putro, P. J. S. \& Suprihatin. Pola Diit Tepat Jumlah, Jadwal, dan Jenis Terhadap Kadar Gula Darah Pasien Diabetes Mellitus Tipe II. Stikes 5, 71-81 (2012).

6. IImah, Farida, Rochmah, T. Kepatuhan Pasien Rawat Inap Diet Diabetes Mellitus Berdasarkan Teori Kepatuhan Niven. J. Adm. Kesehat. Indones. 3, 60-69 (2015).

7. Kim, K., Kim, M. \& Lee, K.-E. Assessment of foodservice quality and identification of improvement strategies using hospital foodservice quality model. Nutr. Res. Pract. 4, 163 (2010).

8. Almatsier, S. Penuntun Diet Edisi Baru. (Gramedia Pustaka Utama, 2010).

9. Soelistijo, S. A. et al. Pengelolaan dan pencegahan diabetes melitus tipe 2 di indonesia 2015. (PB. PERKENI, 2015).

10. Juniawati, Usmiati, S. \& Damayanthi, E. Pengembangan Keju Lemak Rendah Sebagai Pangan Fungsional. Litbang Pertan. 34, (2015).

11. I, F. R. \& Wirawanni, Y. Hubungan Konsumsi Karbohidrat, Konsumsi Total Energi, Konsumsi Serat, Beban Glikemik Dan Latihan Jasmani Dengan Kadar Glukosa Darah Pada Pasien Diabetes Mellitus Tipe 2. JNH 2, (2014).

12. Edy, E. Hubungan Asupan Makronutrien Dengan Nilai Kadar Glukosa Darah Pada Pasien Diabetes Melitus Tipe 2 Dirumah Sakit Umum Panembahan Senopati Bantul Yogyakarta. (Sekolah Tinggi Ilmu Kesehatan Jenderal Achmad Yani Yogyakarta, 2017).

13. Wahyuni, E. S. Evaluasi Tatalaksana Terapi Diet pada Penderita Diabetes Mellitus di Rang Inap Badan RSUD Dr. M. Ashari Pemalang. (2006).

14. Kemenkes RI. Pedoman Perkiraan Jumlah Garam dan Penyerapan Minyak Goreng. (2014).

15. Werdani, A. R. \& Triyanti. Asupan Karbohidrat sebagai Faktor Dominan yang Berhubungan dengan Kadar Gula Darah Puasa. J. K 9, 71-77 (2014). 